\title{
ORGANIZATION BEHAVIOR CHANGES CAUSED BY INFORMATION AND COMMUNICATION TECHNOLOGIES
}

\author{
Khaled Al Majzoub ${ }^{1}$, Vida Davidavičienè ${ }^{2}$ \\ ${ }^{1,2}$ Department of Business Technologies and Entrepreneurship, \\ VGTU, Sauletekio al. 11, 10223, Vilnius, Lithuania

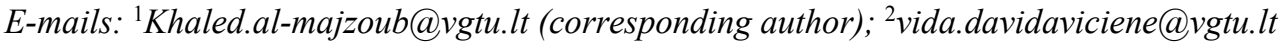

\begin{abstract}
The development and use of Information and communication technology(ICT) is growing at a rapid speed across the world. The number of internet (as well as other technologies) users increased by $27,750 \%$ from 1993 (14 million) until $2017(3,885,567,619)$ users according to internetworldstats. ICT is becoming essentials in all organization, and organizations cannot survive or compete without using these technologies. Although some researches were done on the effects of these technologies on organizations behaviours, they still in initial stages. The following article examine the effect of ICT on organizational behaviours, especially on Organizational Design how ICT changes the organizational structure and what are the organizations formed, Intelligence in what way knowledge is created and strategically used, and Decision Making how it will affect the speed and accuracy of decision making. Methods used in the article are scientific literature analysis, synthesis and comparison.
\end{abstract}

Keywords: information and communication technologies, organizational behaviours, organizational design, organizational change, change management, organizational intelligence, organizational decision making.

JEL Classification: M10, M150.

\section{Introduction}

One of the most inevitable challenges that organizations faces is change, change is a transition from the current state to the desired one. Change happens for many reasons some are Recession, Increasing market pressures, Reduced budget, and Advances in technology (Livingsta, 2017). With the advance and rapid growing and using of ICT, ICT is playing a significance role in organization design by restructuring business practise, creating new job through the introduction of new technology and removing old jobs through automation. Nowadays, organizations exchanging information and knowledge using various information systems and create exclusivity (Abdi et al., 2018; Raudeliūnienė \& Davidavičius, 2017) and customer loyalty (Skačkauskienė, Vilkaitè-Vaitonè, Raudeliūnienè, \& Davidavičienè, 2016). ICT allow to bypass intermediaries, and enhance understanding of their customer's needs, facilitate to create innovations and reduce the operational costs (Ceicyte \& Petraite, 2018; Raudeliūnienè, Davidavičienè, Tvaronavičienè, \& Jonuška, 2018).

Which requires up-to-date organizational design to cope with the change the ICT is bring to the world. Intelligence organizations requires information about their environment to adjust their plans accordingly. Without those information's organizational will not be able to perform. ICT provides organizations with intelligent information through connecting different organizational units together, and by providing tools such as business intelligence (BI) (Gërguri-Rashiti, Abazi-Alili, \& Dika, 2013). Strategic management especially the decision-making process is the most important part of business management, the use of Enterprise resource planning and business intelligence in additional to other ICT system have provide a fast, reliable and intelligent access to databases, which help in taking right decision, since accurate and correct information's are present, In additional to access this information inside and outside the company with an ease where this was not possible before (Bloom, Garicano, Sadun, \& Van Reenen, 2014). Given the importance of companies to possess competitive advantage, survive through this rapid changing world and keep competing, it is essential to study the impact of ICT on organizational change. The purpose is to analysis theories and previous re- 
search studies on impact and changes of the organizational Design how ICT changes the organizational structure and what are the organizations formed, Intelligence in what way knowledge is created and strategically used, and Decision Making how it will affect the speed and accuracy of decision making, and prepare the research structure for identifying gaps, trends and model the contemporary organization management in future.

\section{Organization changes in the ICT development era}

In recent years, the use of ICT is increasing worldwide. According to (internetworldstats, 2017) the number of internet users increased by $27.750 \%$ from 1993 until 2017. ICT refers to Information and communication technology that is related to any product that store, retrieve, transmit and manipulate information's. For example, personal computers, mobile phones, etc. (Riley, 2015). Information and communication technology tools have various advantages which include (Yoon, 2008):

1. It can analyse the huge load of data which is impossible for human to analysis.

2. Provide and produce high amount of information which are impossible for human to produce. For example, Information and communication technology tools can provide relations between technology and corporations and examine technology attributes through statistical analyses.

3. Provide support decision making process by using the stored data.

ICT is becoming an essential part of the organizations with the increase investment on it (Baroudi \& Lucas, 1994) as well as for individual behaviour. So, it could be stated that ICT has direct effect on organizational behaviour especially on organizational design, intelligence and decision making. These three aspects will be analysed and presented further, trying to outline most important key factors in organization behaviour research.

Organizational design is defined as "the way an organization is to be structured and operated by its members. It is both a plan and a process" (Grimsley, 2018). Organization design focus on changing organization structure, which will affect the change in people, tasks and technology. Organisation structure is defined by (Nieuwenhuizen, Badenhorst-Weiss, Rossouw, Brevis, \&
Cant, 2008) as "the arrangement of workflow, communication and authority relationships within an organisation". Information technology changes have introduced four new organizational types, such as virtual organizations, negotiated organizations, traditional organizations and vertically integrated conglomerates organizations. The specific of them is as follows:

- Virtual organizations: The use of technology through email, video conferencing, etc. allowed people to work from different places independent from physical locations, without the need for offices, employee can work from their home or from any coffee shop without the need to be physical available in the company.

- Negotiated organizations: is an organization that deliver its product by coordinating between different companies that make and deliver its product, by using technology like EDI, emails.

- traditional organizations: are organizations that use technology some changes which are not major. Traditional organizations need to move toward a vertical model to improve its responsiveness.

- Vertically Integrated Conglomerates: The usage of electronic exchange of data between customers and suppliers especially when there is imbalance power between them which can cause the other to use and adhere to the other demands using ICT.

As ICT is rapidly growing and the companies are expanding their markets, for me the most convent types to use are virtual organization and negotiated organizations. Virtual organization reduce overhead cost, company that use virtual organizations can spread their employees geographically and organizationally, which will allow it to respond to market changes and customers' demands. Negotiated organizations there is no need for companies to establish office or hire employees which will reduce their cost. They can coordinate between different companies that make and deliver its product through the emails or other forms of communications that ICT provide.

One of proved effect of ICT on organization is to the possibility to reduce layers in organizational hierarchy using computers. Which result simplifying organizational structure, centralize decision at executive level and decentralize it at operation level, it also cause widening in span of control (Bezweek, 2010). Not less important is 
such phenomena as organizational intelligence and its changes in the era of ICT development.

Organizational Intelligence. According to (Halal, 1997) define organizational intelligence as "the capacity of an organization to create knowledge and use it to strategically adapt to its environment." It is similar in purpose to the IQ individual. Most of definitions of organizational intelligence includes the ability of information process or interpretation. According to this author he examines organizational intelligence as a composite of data, information, knowledge, and wisdom (see Figure 1 below).

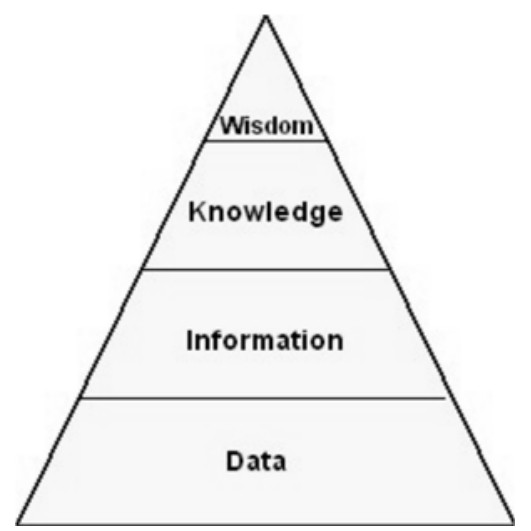

Figure 1. Traditional information concept hierarchy

Data contains no meaning as it is the raw facts. When data are put in a meaningful mean it represents information (Boulesnane, Bouzidi, \& Bouzidi, 2013). Knowledge is defined is the capacity to act and take decision based on experience and study. Unlike data and information, knowledge is related to individual's cognitive skills in solving problems. Wisdom is defined as "a state of the human mind characterized by profound understanding and deep insight". At individual level it is the person ability to make connection between information and knowledge. At organizational level wisdom is the shared and integrated knowledge of individuals, teams, departments levels - this is called the natural intelligence. The taxonomy of organization intelligence was presented and it evolved together with ICT and was influenced by the ICT development (see Figure 2). We have two types of intelligent in organization the natural and the Artificial intelligence. The development of ICT provides organizations with infrastructure to store, share and use the knowledge. In the individual intelligence ICT provides individual with the access to a lot of information through using of Laptops, Smartphones, etc... which accelerate the learning process. In Collective ICT provide tools such as email, web conference so the people inside a company can interact, and last for emergent it emerges for the interact of huge number of people, by using internet, etc.

Another type of intelligence, which presented and defined by scholars and raised as one of ICT development results, is Artificial intelligence (AI). AI is "the part of computer science concerned with designing intelligent computer systems, that is, systems that exhibit the characteristics we associate with intelligence in human behaviour". AI help the users to automate their tasks like administration and team coordination. A survey was done by Harvard business review "though today managers spend more than half of their time on administrative activities and quality control, most of these functions will soon be automated". These tasks with the help of AI can be automated. The future companies will be hierarchy and will be made of supervisor getting their tasks from AI systems. Thus, AI will allow them to focus on things that as human has value to add. AI will automate the most repetitive jobs, which will allow humans to occupy new functions that are more creative by using empathy, collaboration and exchange.

Another aspect for using AI is to use reputation risk management, which was designed to analyse the different and conflict incentives behaviour. This tool is powerful, because inside organization the bad behaviour of employees and managers is tied to financial incentives. For example, the case of the banking scandals where employees used to open thousands of accounts and close, the reason was because their incentive was based on the number of accounts they open.

The requirements for Artificial intelligence is less than the natural intelligence, with the advance of information and communication technology the role of AI will increase.

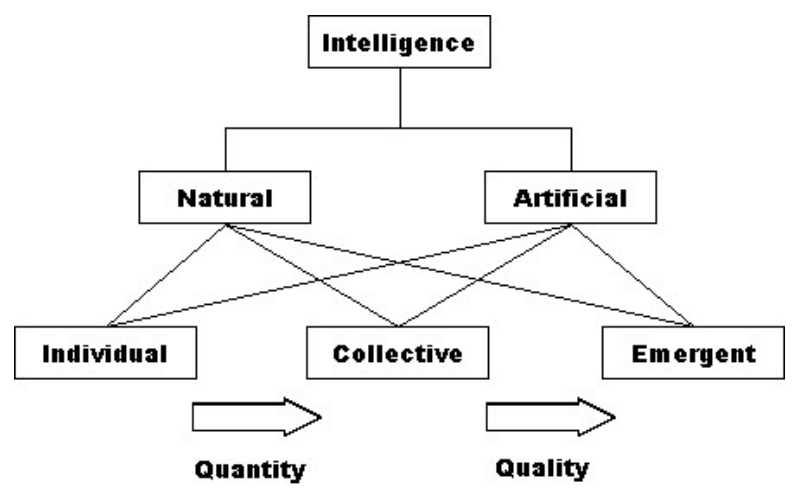

Figure 2. Taxonomy of Intelligence 
The organizational intelligent is not only the sum of intelligence of employees in organization, even if organization learning dealt with collective intelligence and how it is important to create synergy between departments. Emergent intelligence as a phenomenon is studied important to create synergy between departments. Emergent intelligence as a phenomenon is studied less in organizations. EI is the intelligent behaviour emerged from the interaction between large numbers of employees in organizations. Internet and advance in information technology have it is power in achieving this, people can communicate and share their ideas and behaviour over the internet using forums, blogs, etc. Inside companies' systems like skype for business or conference calls can allow such interactions between the company employees.

Glynn (1996) divided the organizational intelligence into three categories: the aggregate of individual intelligence; the interrelation of individual intelligence; intelligence of the organization itself as a larger system. Using the taxonomy OI is divided into three levels: Individual (Intelligence at individual level); Collective (includes the sum of individuals intelligence); Emergent (it emerges for the interactions between individuals). This deviation will be used in future research of organizational change.

Decision making. For many research the decision making process is to choose the suitable solution from different available solutions to the current issue (Boulesnane et al., 2013). According to Zeleny (2011) decision-making process is "an act of selecting the most desirable alternative and treats it, instead, as a process: a dynamic and interrelated unity of precision, decision and post decision stages". According to (Huarng, Mas-Tur, \& Calabuig Moreno, 2018) "Decision-making is an intentional process that combines the analysis of information, the evaluation of alternatives, and the decision itself. Strategic decision-making is crucial for implementing business strategies".

People needs to analyse a lot of data to reach a strategic decision making, and the problem is not about how to store these data but how to manage them (Boulesnane et al., 2013). The advance in Information and communication technology make it easier and cheaper to store, reuse and manage data (Hedelin \& Allwood, 2002). Organizations are taking advantage of these new Information and communication technologies to develop a platform to facilitate the sharing of this knowledge (Rumizen, 1998) According to
(Brown \& Ross, 1996) a well-developed infrastructure ICT provides two important strategic capabilities:

1. This infrastructure will enable organize functions and divisions to communicate and share information, which will support cross-functional decision making

2. Organization will be able to act more globally

Naturalistic design making is usually done by experience, and not by thinking about the current situation and analysis of information, because sometimes information are huge to decode and

analyses to reach a timely reasonable decision making especially if there a time pressure exist (Hedelin \& Allwood, 2002).

ICT provides the business with the required tools that will help and simplify the process of achieving decision making process. The role of technology in decision making were defined by:

1. Data Processing Capabilities: ICT will enable you to analyse and process huge information of data, through providing tools such as data mining and data warehouse

2. IT brings speed: ICT allows you to access millions of information and retrieve data in few seconds

3. IT Supports group decision making: It allows groups of people to make decision through providing them with the required tools such as group decision support system (GDSS).

To conclude, organizations are changing by time and the development of ICT is rapidly growing. Organizations must adapt their changes to the new ICT to stay and gain competitive advantage. Some of the major changes caused by ICT at organizational design is the change in structure and creation of new organizational like Virtual organization, widening span of control, allowing organization to be more horizontal. In organization intelligence is the use of AI, effective knowledge management, frictionless access to resources, and organizational learning using ICT, data can be stored, retrieved and executed more effectively with the use of ICT. In decision making, ICT introduced systems like Executive information system (EIS) and Decision support system (DSS) that support managers decisions by providing models for analysing and processing data. Future research must include the use of AI in decision making, how AI will help decision making by systems that learn by collecting data and process information 
and choose the optimal decision based on the fact retrieved.

\section{ICT adoption and evaluation}

The following theories for adoption of ICT are most often used: the technology acceptance model (TAM); Theory of planned behaviour (TPB); Unified theory of acceptance and use of technology (UTAUT); Diffusion of innovation theory (DOI).

The technology acceptance model (TAM): explain how the technology is perceived and used by the users. TAM is based on two factors: 1) perceived usefulness: refers to how the user will see the technology beneficial to his work, what benefits he will get from using this technology; 2) perceived ease of use: refers to how this technology requires easy effort to use, and it is not hard or complicated

Theory of planned behaviour (TPB) was developed by Icek Ajzen in 1991. The theory proposed three factors to how user will adopt the technology: attitude towards act or behaviour: How this act will impact a good or negative behaviour to the user life; subjective norm: its related to everything that surround the user like social network, culture, etc.; perceived Behaviour control: person believe on how it is easy to behave or act in a certain way.

Diffusion of innovation theory (DOI) was developed by Evertt Rogers in 1962. The theory explains how innovation is adopted over time and how technology is spread. According to evert diffusion happens through five stages of decision making: knowledge (in this stage the person is exposed to the innovation but, yet he does not have the information that will require him to do find more about); persuasion (the individual now will involve in action more about the innovation); decision (the individual now will weigh the positive and negative effects of the innovation and decide whether to use or no); implementation (the extent to which the individual can test the innovation); confirmation (the individual finalizes if he will continue to use the innovation). DOI also divide the adopters into five categories: innovators (are risk tolerance takers and they are the first to use the innovation even they do not have enough information about it); early adopters (are the second wave, the product is maturing); early majority (are the third wave, the use the innovation when it is widely known); late majority (they are cautions and wait for decline prices); laggards (are the last, they are reluctant, and they may use or may not use the innovation).
Unified theory of acceptance and use of technology (UTAUT): It was developed by Venkatesh and others in 2003. It is another theory in user of accepting and using information technology systems, it is based on four theoretical constructs:

- Performance Expectancy: is the system going to speed up the task I am doing

- Effort expectancy: how easy is the system to use

- Social influence: how it is perceived by other people that he should use the system

- Facilitating conditions: How well the organizational infrastructure exists to be able to use the system

In addition to this variable, there are moderating factors which moderate the relations between the above-mentioned constructs and accepting and using the systems. These moderating factors are Gender, Age, Experience and voluntaries of use. All the above theories explain the attitudes of individuals towards ICT and the intention to use, adopt and accept these systems. The most relevant model my search problem is the technology acceptance model (TAM) and theory of planned behaviour (TPB) because both concentrate on the usefulness and ease of use, which will be helpful in studying the effect of AI in decision making. TAM \& TPB theories used in e-commerce by SMEs "The introduced constructs in the integrated framework (e.g. company mission, individual difference factors, perceived trust and perceived service quality) introduce socio-technical systems and improve the theoretical base of adoption".

\section{Information systems in organizations}

Information and communication technology help building and sustaining organizational intelligence through the creating and supporting the four modules of organizational intelligence (Data, Information, Knowledge and Wisdom). Using ICT systems like Database (DB), Knowledge management (KM), Enterprise resource planning (ERP), Intelligence decision support (IDS) etc.

Table 1 present the ICT influence on organizational behaviour.

For companies to stay ahead gain and sustain competitive advantage they must monitor threats and detect potential opportunities. This involves the use of information systems where the accuracy of the data is the most important part. For example the most important part to start with are the stor- 
age and capturing of data as in Transaction processing system (TPS) and The transactional information systems (STT), without having correct data Intelligence and decision making of company cannot be reached, since it cannot be based on wrong or inaccurate data, which will lead to false use of decision and intelligence inside the organization.

Table 1. IS influence on organization behaviour (source: compiled by authors)

\begin{tabular}{|c|c|c|c|c|}
\hline IS/ ICT type & $\begin{array}{c}\text { Organization } \\
\text { design }\end{array}$ & $\begin{array}{l}\text { Organization } \\
\text { intelligence }\end{array}$ & $\begin{array}{c}\text { Decision } \\
\text { making }\end{array}$ & Explanation \\
\hline $\begin{array}{l}\text { Transaction pro- } \\
\text { cessing system (TPS) }\end{array}$ & & + & & collect and stores transactional data \\
\hline $\begin{array}{l}\text { Management infor- } \\
\text { mation system (MIS) }\end{array}$ & & + & & $\begin{array}{l}\text { convert the collected transactional data into } \\
\text { information to provide planning and manag- } \\
\text { ing of organization }\end{array}$ \\
\hline $\begin{array}{l}\text { Decision support sys- } \\
\text { tem (DSS) }\end{array}$ & & + & + & $\begin{array}{l}\text { support managerial decisions by providing } \\
\text { models for analysing and processing data; } \\
\text { support decision making when the problem } \\
\text { is unstructured }\end{array}$ \\
\hline $\begin{array}{l}\text { Executive information } \\
\text { system (EIS) }\end{array}$ & & + & & $\begin{array}{l}\text { provides senior levels with required data to } \\
\text { monitor organizational performance }\end{array}$ \\
\hline $\begin{array}{l}\text { On-line analytical } \\
\text { processing (OLAP) }\end{array}$ & & + & & $\begin{array}{l}\text { multidimensional view of data regardless of } \\
\text { how data is stored }\end{array}$ \\
\hline Data mining & & + & & $\begin{array}{l}\text { use of artificial intelligence and statistical } \\
\text { analysis to find and identify hidden infor- } \\
\text { mation in data }\end{array}$ \\
\hline $\begin{array}{l}\text { Group decision sup- } \\
\text { port system (GDSS) }\end{array}$ & & & + & $\begin{array}{l}\text { These facilities the decision across team } \\
\text { members }\end{array}$ \\
\hline $\begin{array}{l}\text { Geographical infor- } \\
\text { mation systems (GIS) }\end{array}$ & & & + & $\begin{array}{l}\text { This decision support system is used in spa- } \\
\text { tial information that are related to locations }\end{array}$ \\
\hline $\begin{array}{l}\text { Artificial intelligence } \\
\text { (AI) }\end{array}$ & & & + & $\begin{array}{l}\text { These systems are designed to imitate hu- } \\
\text { man thinking }\end{array}$ \\
\hline Expert systems & & & + & $\begin{array}{l}\text { it is an AI system that apply reasoning to } \\
\text { reach a decision }\end{array}$ \\
\hline Genetic algorithm & & & + & $\begin{array}{l}\text { artificial intelligence(AI) system that pro- } \\
\text { vides better solutions to a problem }\end{array}$ \\
\hline $\begin{array}{l}\text { Business Intelli- } \\
\text { gence(BI) }\end{array}$ & & + & + & $\begin{array}{l}\text { Collection, integration and analysis of busi- } \\
\text { ness information }\end{array}$ \\
\hline $\begin{array}{l}\text { Enterprise resource } \\
\text { planning (ERP) }\end{array}$ & + & + & + & $\begin{array}{l}\text { common process and data model for the or- } \\
\text { ganization end to end processes for finance, } \\
\text { supply chain and HR }\end{array}$ \\
\hline Cloud computing & & + & + & $\begin{array}{l}\text { Use network of host servers on internet to } \\
\text { store, manage and process data, instead of } \\
\text { having local server for the organization }\end{array}$ \\
\hline $\begin{array}{l}\text { Management Systems } \\
\text { database (DDBMS) }\end{array}$ & & + & + & $\begin{array}{l}\text { Provides data management, storage, coher- } \\
\text { ence and sharing between different business } \\
\text { functions }\end{array}$ \\
\hline Expert systems & & + & + & $\begin{array}{l}\text { Act as consultant provides advice to man- } \\
\text { agement }\end{array}$ \\
\hline $\begin{array}{l}\text { The transactional in- } \\
\text { formation systems } \\
\text { (STT) }\end{array}$ & + & & + & $\begin{array}{l}\text { store and execute routine transactions oc- } \\
\text { curred during commercial activities (sales, } \\
\text { purchases, deposits, withdrawals, pay- } \\
\text { ments). }\end{array}$ \\
\hline $\begin{array}{l}\text { Strategic information } \\
\text { systems (SIS) }\end{array}$ & + & + & + & $\begin{array}{l}\text { located at all levels inside the company and } \\
\text { they influence, goals, operations, products } \\
\text { and services or relationships with environ- } \\
\text { mental organizations to enable them to stay } \\
\text { ahead of the competition. }\end{array}$ \\
\hline Office systems (SB) & + & & & $\begin{array}{l}\text { Like word, excel, etc... designed to improve } \\
\text { work at office }\end{array}$ \\
\hline
\end{tabular}




\section{Conclusions}

The rapid speed of development and progress of information and communication technology has its effect on organizational behaviour especially on organizational design, organizational intelligence decentralize it at operation level, it also cause widening in span of control and organizational decision making.

ICT caused changes in organizational design new organization created Virtual organizations, Negotiated organizations, traditional organizations and Vertically Integrated Conglomerates. ICT found to reduce layers in organizational hierarchy using computers. Which will result in simplifying organizational structure, centralize decision at executive level and level and decentralize it at operation level, it also cause widening in span of control.

Organizational intelligent is a key aspect for a company to develop and maintain it is competitive advantage, by using ICT a company can store data and generate from it a dashboards which continues useful information that can help in making the correct decisions, also it can analyse and process a huge amount of information that are impossible for a human alone to achieve.

Decision making are essentials for organizations to choose the optimal decision from alternative, ICT provide systems like Decision support system (DSS), Executive information system (EIS) and On-line analytical processing (OLAP) that will help in achieving the optimal decisions. I purpose the following for future research, first the effect of ICT adoption theories on the current contemporary organizations, how they will help organizations to implement and use new systems, second to examine the relationship between organizational design, intelligence and decision making how each one will affect the other, and third what are the benefits regarding cost vs benefits (e.g.: providing competitive edge) for using ICT in contemporary organizations.

\section{References}

Abdi, K., Mardani, A., Senin, A. A., Tupenaite, L., Naimaviciene, J., Kanapeckiene, L., \& Kutut, V. (2018). The effect of knowledge management, organizational culture and organizational learning on innovation in automotive industry. Journal of Business Economics and Management, 19(1), 1-19.

https://doi.org/10.3846/jbem.2018.1477

Baroudi, J. J., \& Lucas, J. H. C. (1994). The role of information technology in organization design. Journal of Management Information Systems, 10(4), 9-23.

Bezweek, A. (2010, May). The impact of information technology to facilitate communication and collaboration in Libyan public organisations. $C I B$ World Congress 2010 (pp. 1-15). The Lowry, Salford Quays, United Kingdom.

Bloom, N., Garicano, L., Sadun, R., \& Van Reenen, J. (2014). The distinct effects of information technology and communication technology on firm organization. Management Science, 60(12), 2859-2885. https://doi.org/10.1287/mnsc.2014.2013

Boulesnane, S., Bouzidi, L., \& Bouzidi, L. (2013). The mediating role of information technology in the decision-making context. Journal of Enterprise Information Management, 26(4), 387-399. https://doi.org/10.1108/JEIM-01-2012-0001

Brown, C. V., \& Ross, J. W. (1996). The information systems balancing act: building partnerships and infrastructure. Information Technology \& People, 9(1), 49-62. https://doi.org/10.1108/09593849610111571

Ceicyte, J., \& Petraite, M. (2018). Networked responsibility approach for responsible innovation: perspective of the firm. Sustainability, 10, 1-15. https://doi.org/10.3390/su10061720

Gërguri-Rashiti, S., Abazi-Alili, H., \& Dika, Z. (2013). The use of ICT in the decision making process: the case of Macedonian entrepreneurial businesses, Entrepreneurship in the Balkans. Berlin, Heidelberg: Springer Berlin Heidelberg.

Glynn, M. A. (1996). Innovative genius: a framework for relating individual and organizational intelligences to innovation. The Academy of Management Review, 21(4), 1081.

https://doi.org/10.5465/amr.1996.9704071864

Grimsley, S. (2018). Organizational design: theory, principles, definition. Retrieved from https://study.com/academy/lesson/organizationaldesign-theory-principles-definition.html.

Halal, E. W. (1997). Organizational intelligence: what is it, and how can managers use it?. Retrieved from https://www.strategybusiness.com/article/12644? gko=4a546.

Hedelin, L., \& Allwood, C. M. (2002). IT and strategic decision making IT and strategic decision making. Industrial Management \& Data Systems, 102(1), 125139. https://doi.org/10.1108/02635570210421318

Huarng, K. H., Mas-Tur, A., \& Calabuig Moreno, F. (2018). Innovation, knowledge, judgment, and decisionmaking as virtuous cycles. Journal of Promotion Management, 24(5), 1-3. https://doi.org/10.1016/j.jbusres.2018.02.031

Internetworldstats. (2017). Internet growth statistics 1995 to 2017 - the global village. Retrieved from https://www.internetworldstats.com/emarketing.htm.

Livingsta. (2017). Respond to change in a business environment: causes and effects of change. ToughNickel. Retrieved from https://toughnickel.com/ business/Respond-to-Change-in-a-Business-Environment-Understand-the-causes-and-effects-of-change.

Nieuwenhuizen, C., Badenhorst-Weiss, H., Rossouw, D., Brevis, T., \& Cant, M. (2008). Business management: a contemporary approach. Double Storey Publishers.

Raudeliūnienè, J., Davidavičienè, V., Tvaronavičienė, M., Jonuška, L. (2018). Evaluation of advertising campaigns on social media networks. Sustainability, 10(4), 1-14. https://doi.org/10.3390/su10040973

Raudeliūnienè, J., \& Davidavičius, S. (2017). A conceptual model of assessment of knowledge transfer to consumer. Business, Management and Education, 15(2), 174-195. https://doi.org/10.3846/bme.2017.387 
Riley, J. (2015). What is ICT?. Retrieved from https://www.tutor2u.net/business/reference/what-is-ict.

Rumizen, M. (1998). Site visit: how Buckman Laboratories' shared knowledge sparked a chain reaction. Journal of Quality \& Participation, 21(4), 34-38.

Skačkauskienè, I., Vilkaitè-Vaitonè, N., Raudeliūnienė, J., \& Davidavičienè, V. (2016). A model for measuring passenger loyalty. Transport, 31(1), 100-107.

https://doi.org/10.3846/16484142.2015.1094748
Yoon, B. (2008). On the development of a technology intelligence tool for identifying technology opportunity. Expert Systems with Applications, 35 (1-2), 124-135.

https://doi.org/10.1016/j.eswa.2007.06.022

Zeleny, M. (2011). Multiple criteria decision making (MCDM): from paradigm lost to paradigm regained? Multiple Criteria Decision Making: Challenges and Advancements, 18(1-2), 77-89.

https://doi.org/10.1002/mcda.473 